\title{
Pemeriksaan Status Gizi Indeks Massa Tubuh Menurut Umur untuk Deteksi Dini Status Gizi Tidak Normal pada Remaja Puteri
}

\author{
Atikah Rahayu \\ Departemen Gizi Program Studi Kesehatan Masyarakat, Fakultas Kedokteran, Universitas Lambung \\ Mangkurat, Banjarmasin, Indonesia \\ Email: nindya.fitria@gmail.com
}

Submitted : 23/04/2020

Accepted: 05/05/2020

Published:16/06/2020

\begin{abstract}
Macro and micro nutrient deficiency in female adolescents causes the body to be thin and weight (BB) to drop dramatically impact on nutritional status becomes abnormal. One risk factor is an unbalanced diet. The nutritional status of adolescent girls can be seen from the results of the examination of Body Mass Index (BMI / U) by age. The importance of this nutritional status check is carried out considering that adolescent girls are one of the most potential human resources to assist development in a country because adolescents are the next generation and determiners of the future of this nation, in addition, adolescent girls are prospective mothers who will give birth to children of high quality to use for the development of a nation if it consumes food based on balanced nutrition. The examination of abnormal nutritional status of 68 teenage girls (39.3\%) can trigger educational institutions in collaboration with health institutions and parents to immediately conduct nutritional interventions in the form of nutritional education, or cooking demonstrations of balanced nutrition requirements for teenagers and parents as a program to tackle problems of abnormal nutritional status and the risk of anemia for adolescent girls, so that nutritional problems in adolescents can be quickly resolved.
\end{abstract}

Keywords: adolescents, BMI, early detection, nutritional status

\begin{abstract}
Abstrak
Kurang zat gizi makro dan mikro pada remaja puteri menyebabkan tubuh menjadi kurus dan berat badan (BB) turun drastis berdampak status gizi menjadi tidak normal. Salah satu faktor risikonya adalah pola makan yang tidak seimbang. Status gizi remaja putri dapat dilihat dari hasil pemeriksaan Indeks Massa Tubuh (IMT/U) menurut umur. Pentingnya pemeriksaan status gizi ini dilakukan mengingat remaja puteri salah satu SDM yang paling potensial untuk membantu pembangunan dalam sebuah negara karena remaja merupakan generasi penerus dan penentu masa depan bangsa ini, selain itu remaja puteri merupakan calon ibu yang akan melahirkan anak-anak yang berkualitas bergunak untuk pembangunan suatu bangsa jika mengonsumsi makanan yang berpedoman pada gizi seimbang. Hasil pemeriksaan status gizi tidak normal sebesar 68 remaja puteri $(39,3 \%)$ dapat memicu institusi pendidikan bekerjasama dengan institusi kesehatan serta orang tua untuk segera melakukan intervensi gizi dapat berupa pendidikan gizi, ataupun demo masak syarat gizi seimbang bagi remaja maupun orang tua sebagai program penanggulangan masalah status gizi tidak normal dan risiko anemia bagi remaja puteri, sehingga masalah gizi pada remaja dapat cepat teratasi.
\end{abstract}

Kata kunci: deteksi dini, IMT, status gizi, remaja

\section{PENDAHULUAN}

Masalah gizi masih merupakan beban berat bagi bangsa terutama permasalahan gizi pada remaja. Pengaruh masalah gizi terhadap pertumbuhan, perkembangan, intelektual dan produktivitas menunjukkan besarnya peranan gizi bagi kehidupan pada masa remaja. Apabila terjadi gangguan gizi pada masa remaja maka pertumbuhan dan perkembangan tidak akan berlangsung optimal. Remaja dapat menjadi sumber daya manusia (SDM) yang berkualitas jika sejak dini terpenuhi kebutuhan gizinya, sehingga dapat menjadi SDM yang paling 
potensial untuk membantu pembangunan dalam sebuah negara karena remaja merupakan generasi penerus dan penentu masa depan bangsa. (Yuliansyah, D., 2007; Setijowati N, Karunia L, Magdalena N, 2013). Remaja putri mempunyai risiko tinggi untuk anemia. Arisman (2004) menyebutkan bahwa, penyebab remaja putri merupakan kelompok berisiko tinggi menderita anemia dikarenakan, pada umur tersebut terjadi peningkatan kebutuhan zat besi akibat pertumbuhan, adanya menstruasi, sering membatasi konsumsi makan, serta pola konsumsinya sering menyalahi kaidah-kaidah ilmu gizi. Jumlah populasi anak umur sekolah (usia 10-19 tahun) sekitar 40 juta dari 230 juta penduduk Indonesia. Sebanyak 50\% diantaranya adalah kelompok wanita yang berisiko tinggi terhadap anemia (Yuliansyah, D., 2007; Kirana D.P., 2011).

Prevalensi anemia di Indonesia berdasarkan data Departemen Kesehatan (Depkes) RI tahun 2006, yaitu sebanyak $28 \%$ remaja putri mengalami anemia dan berdasarkan data hasil Riskesdas tahun 2007 dapat diketahui bahwa prevalensi anemia pada perempuan dewasa di Indonesia sebesar $19,7 \%$ dimana $70,1 \%$ adalah anemia defisiensi besi. Berdasarkan data Departemen Kesehatan (Depkes) tahun 2008 menunjukkan prevalensi anemia di Indonesia masih cukup tinggi, pada remaja wanita sebesar $26,50 \%$, wanita usia subur (WUS) $26,9 \%$, ibu hamil 40,1\% dan anak balita 47,0\% (Kemenkes RI, 2010: Kemenkes RI, 2013; Dinas Kesehatan Kabupaten Banjar, 2018). Berdasarkan hasil penilaian status anemia pada remaja putri siswi sekolah menengah pertama (SMP)/madrasah tsanawiyah (MTs) yang dilakukan oleh Dinas Kesehatan Kabupaten Banjar tahun 2012, sebesar $65,21 \%$ remaja putri berstatus anemia sebelum diberi perlakuan meminum suplemen zat besi dan setelah diberi perlakuan meminum seplemen zat besi prevalensi anemia menjadi sebesar 27,29\%. Prevalensi anemia di wilayah Kabupaten Banjar tersebut berdasarkan ketentuan WHO (2001) dikategorikan sebagai masalah kesehatan masyarakat yang berat dan sedang karena $>15 \%$. Tentunya masalah anemia ini perlu mendapat perhatian khusus di wilayah Kabupaten Banjar (World Health Organization (WHO), 2010; Nursari, 2013).

Salah satu penyebab terjadinya kejadian anemia adalah asupan zat gizi yang tidak mencukupi. Pada remaja putri yang cenderung lebih memperhatikan penampilan dirinya, seringkali terlalu ketat dalam pengaturan pola makannya karena tidak ingin menjadi gemuk, sehingga dapat mengakibatkan kekurangan zat gizi. Pengaturan pola makan yang menyalahi kaidah gizi seperti ini membuat tingkat pemenuhan kebutuhan tubuh terhadap zat gizi sering tidak terpenuhi. Ketidakseimbangan antara konsumsi makanan dan kebutuhan tubuh akan zat gizi tersebut juga merupakan salah satu faktor yang dapat mempengaruhi kejadian anemia. Tidak terpenuhinya asupan zat gizi penting seperti kekurangan konsumsi energi dan protein dapat menurunkan kadar hemoglobin dalam darah (Nursari, 2013; Gunatmaningsih D, 2017). Berdasarkan penelitian Kwatrin (2007) dalam Nursari (2013) dimana remaja putri dengan asupan energi $<100 \%$ angka kecukupan gizi (AKG) memiliki risiko mengalami anemia 6,962 kali lebih besar dibandingkan remaja putri yang konsumsi energinya cukup. Penelitian Safyanti (2002) dalam Nursari (2013) juga mendapatkan hasil bahwa remaja putri yang asupan proteinnya kurang dari AKG memiliki risiko 5,3 kali lebih besar terkena anemia dibandingkan dengan remaja putri yang asupannya cukup (Nursari, 2013).

Tidak terpenuhinya berbagai asupan zat gizi yang penting bagi tubuh, menyebabkan berbagai masalah pada status gizi yang juga berakibat pada status anemia remaja puteri. Penelitian Gunatmaningsih (2017) didapatkan hasil adanya hubungan antara status gizi dengan kejadian anemia 
pada remaja putri, hal ini menunjukkan bahwa remaja puteri dengan status gizi tidak normal mempunyai risiko 2,175 kali lebih besar untuk mengalami kejadian anemia (Gunatmaningsih D, 2017; Almatsier S, 2010). Pola makan yang tidak seimbang tersebut, akan mempengaruhi status gizi remaja putri. Status gizi pada remaja putri di Indonesia yaitu kurang zat gizi makro (karbohidrat, protein, lemak), kurang zat gizi mikro (vitamin dan mineral). Kurang zat gizi makro dan mikro menyebabkan tubuh menjadi kurus dan berat badan (BB) turun drastis, stunting, anemia, dan sakit terus menerus (12). Status gizi remaja putri tersebut dapat dilihat dari hasil pengukuran indeks massa tubuh (IMT) dan lingkar lengan atas (LLA). Berdasarkan penelitian Bhargava et al. (2001) di Bangladesh dalam Purba (2011) diperoleh hasil bahwa ada hubungan antara IMT dengan status zat besi dalam tubuh. Demikian juga penelitian Antelman et al. (2000) di Tanzania dalam Purba (2011) menunjukkan bahwa, ada perbedaan yang signifikan anemia dengan IMT $<19 \mathrm{~kg} / \mathrm{m} 2$ dan IMT > $24 \mathrm{~kg} / \mathrm{m} 2$, di mana remaja putri yang memiliki IMT $<19 \mathrm{~kg} / \mathrm{m} 2$ memiliki peluang risiko menderita anemia 3 kali lebih besar daripada remaja putri dengan IMT > $24 \mathrm{~kg} / \mathrm{m} 2$. Hasil penelitian Hapizah et al. (2019) di Indonesia dalam Purba (2011) diperoleh ada hubungan berat badan dan tinggi badan dengan kadar $\mathrm{Hb}$ (Hapzah, Yulita R., 2012). Apabila sejak remaja seorang wanita menderita masalah anemia, maka akan mengakibatkan pertumbuhan dan perkembangan terganggu, lemah karena sering terkena penyakit infeksi, tidak aktif, malas, cepat lelah, di sekolah sulit berkonsentrasi dalam belajar dan mengantuk. Akibat lebih lanjut dari masalah anemia ini akan mempengaruhi kecerdasan dan daya tangkapnya mengingat mereka masih dalam masa pertumbuhan dan perkembangan (Farida I, 2018). Oleh karena itu, deteksi dini status gizi remaja pada remaja putri tingkat SMP di wilayah
Kabupaten Banjar penting sekali, guna menghindari permasalahan gizi lanjut yang berdampak pada kualitas sumberdaya manusia mendatang.

\section{TARGET DAN LUARAN}

Target luaran dari kegiatan pengabdian masyarakat ini adalah: (a). Diperolehnya perilaku positif khususnya perilaku yang mengarah pada perbaikan status gizi remaja puteri, (b). Penambahan wawasan remaja puteri terkait cara menilai status gizi dengan antropometri. (c). Diperolehnya pengetahuan gizi masyarakat khususnya remaja puteri terkait dengan pengetahuan status gizi, dan faktor risiko terjadinya anemia. (d). Bahan masukan bagi institusi kesehatan dan pendidikan untuk menyelenggarakan intervensi program gizi.

\section{METODE PELAKSANAAN}

Tiga Sekolah Menengah pertama terpilih yang ada di Wilayah Kabupaten Banjar akan dilakukan pemeriksaan terhadap status gizi remaja puteri.menggunakan IMT/U (Indeks Massa Tubuh menurut umur) setelah sebelumnya saling berkoordinasi dengan Dinas Kesehatan, Dinas Pendidikan Kabupaten Banjar dan SMP setempat. Terkait kegiatan pemeriksaan status gizi. Pemeriksaan status gizi dilakukan pada tiap kelas di 3 SMP tersebut dan dipilih remaja puteri sebagai objek pemeriksaan. Status gizi tidak normal yang diperoleh dari hasil pemeriksaan pada 3 SMP akan direkapitukasi dan selanjutnya dilakukan pelaporan. Laporan tersebut dapat dimanfaatkan Dinas Kesehatan bekerjasama dengan Dinas Pendidikan dalam melakukan intervensi gizi sebagai rekomendasi program penanggulangan masalah status gizi dan risiko anemia remaja puteri.

Adapun tahapan pelaksanaan pengabdian masyarakat terdiri atas 3 tahapan yaitu 1). Tahap Perencanaan, 2). Tahap pelaksanaan, 3) Tahap Penyelesaian. Dalam tahap perencanaan yaitu Pada 
tahap ini mendapatkan perizinan pada Badan Pelayanan Perizinan Terpadu (BP2T), Dinas Pendidikan Kabupaten Banjar Dinas Kesehatan Kabupaten Banjar, dan sekolah yang akan dijadikan tempat penelitian meliputi gambaran umum, letak geografis, dan data jumlah siswi. Selain itu, mempersiapkan instrumen penelitian, seperti lembar informed consent, lembar isian, kalibrasi pada timbangan injak biasa sebelum berat badan ditimbang dengan ketelitian penimbangan $0,1 \mathrm{~kg}$, kalibrasi mikrotoise dengan kapasitas ukur 2 meter dan ketelitian $0,1 \mathrm{~cm}$ dan pembekalan kepada enumerator yang membantu pelaksanaan pemberdayaan disekolah. Enumerator pada penelitian ini adalah mahasiswa/i PSKM FK UNLAM semester IV. Pembekalan dilakukan untuk menyamakan persepsi antara pengusul pemberdayaan dalam kegiatan pengabdian masyarakat dengan enumerator berupa penjelasan mengenai cara pengukuran IMT. Dalam tahap pelaksanaan yaitu melakukan pada kegiatan pemberdayaan masyarakat melalui pemeriksaan status gizi ini bertujuan untuk mendeteksi status gizi tidak normal yang dialami remaja puteri dengan mengukur berat badan dan tinggi badan kemudian direfleksikan menurut umur remaja puteri, sedangkan pada tahap penyelesaian yaitu Data hasil ukur berat badan dan tinggi badan yang telah diperoleh dintepretasikan menggunakan baku rujukan WHO 2006 dengan menggunakan indeks IMT/U ((Indeks Massa Tubuh menurut umur). Hasil yang telah diintepretasi dikategorikan dalam 2 kategori status gizi normal dan tidak normal. Kemudian disajikan dalam tabel distribusi frekuensi. Adapun alur kegiatan lebih detail terdapat pada Gambar 1.

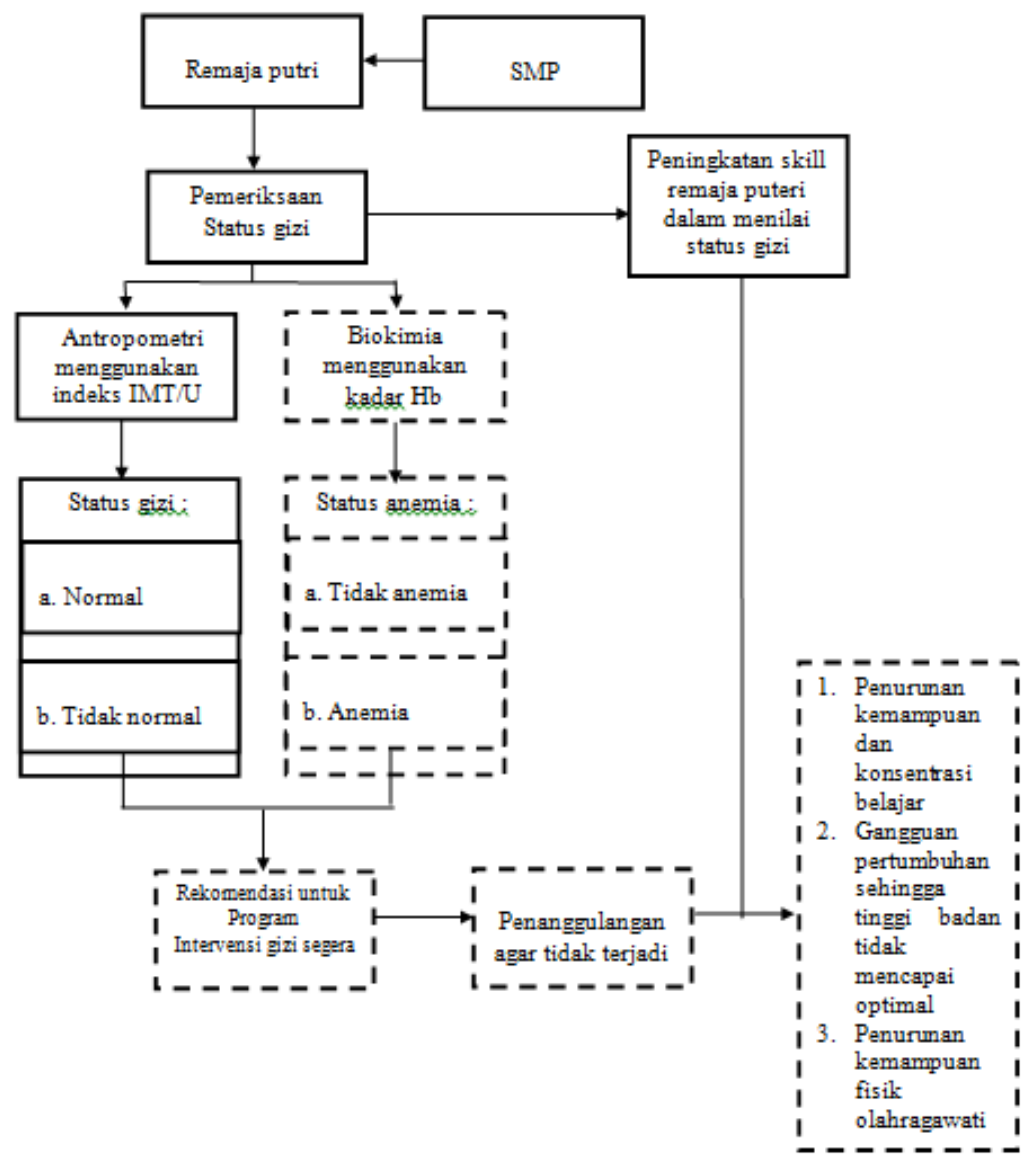

Gambar 1. Alur pelaksanaan pemeriksaan status gizi pada remaja puteri dan kemanfaatannya bagi remaja dan institusi terkait 


\section{HASIL DAN PEMBAHASAN}

\section{Hasil Kegiatan Pemeriksaan Status Gizi Pada Remaja Puteri}

\section{Umur remaja puteri}

Umur memiliki peranan penting dalam menentukan pemilihan makanan. Saat seseorang tumbuh menjadi remaja dan dewasa, pengaruh terhadap kebiasaan makan sangat kompleks. Umur responden di atas tergolong dalam masa remaja awal. Masa remaja awal berada pada rentang usia 12-15 tahun. Pada rentang umur ini remaja mengalami pertumbuhan jasmani yang sangat pesat dan perkembangan intelektual yang sangat intensif, sehingga minat anak pada dunia luar sangat besar dan pada saat ini remaja tidak mau dianggap kanak-kanak lagi, namun belum bisa meninggalkan pola kekanak-kanakannya.

Remaja putri juga merupakan salah satu kelompok yang berisiko menderita anemia. Remaja putri adalah calon ibu yang akan melahirkan generasi penerus dan merupakan kunci perawatan anak di masa datang. Oleh karena itu, kualitas remaja putri perlu mendapat perhatian khusus. Remaja putri mempunyai risiko tinggi untuk anemia karena pada umur ini terjadi peningkatan kebutuhan zat besi akibat pertumbuhan, adanya menstruasi, sering membatasi konsumsi makan, serta pola konsumsinya sering menyalahi kaidahkaidah ilmu gizi (Permaesih D, Herman S. 2015).

Berdasarkan hasil pemeriksaaan status gizi remaja menurut umur di 3 SMP Wilayah kabupaten Banjar menunjukkan bahwa umur 173 remaja puteri yang dipilih sebagai sampel dalam pemberdayaan ini. Dari 173 remaja puteri, terdapat 1 orang $(0,6 \%)$ remaja puteri berumur $<12$ tahun, $103(43,4 \%)$ orang, berumur 12-14 tahun dan 56 remaja puteri $(56 \%)$ berumur $>14$ tahun. Adapun secara rinci umur remaja puteri tersaji pada tabel 1 .
Tabel 1. Distribusi dan Frekuensi Umur remaja puteri

\begin{tabular}{ccc}
\hline Umur & Jumlah & $\begin{array}{c}\text { Persentase } \\
(\%)\end{array}$ \\
Responden & & 0,6 \\
$<12$ tahun & 1 & 43,4 \\
$12-14$ tahun & 103 & 56 \\
$>14$ tahun & 69 & 100 \\
\hline Jumlah & 173 &
\end{tabular}

\section{Status gizi remaja puteri menurut IMT/U}

Pengukuran paling reliabel untuk ras spesifik dan popular untuk menentukan status gizi pada masa remaja saat ini adalah IMT. Pada periode remaja, 20 persen tinggi badan dan 50 persen berat badan saat dewasa telah dicapai. Oleh karena itu kebutuhan zat gizi mencapai titik tertinggi saat remaja dan adanya kekurangan zat gizi makro dan mikro dapat mengganggu pertumbuhan dan menghambat pematangan seksual. Wanita yang berstatus gizi baik akan lebih cepat mengalami pertumbuhan badan dan akan lebih cepat mengalami menstruasi. Sebaliknya wanita yang berstatus gizi buruk pertumbuhannya akan pelan dan lama serta menstruasinya akan lebih lambat. IMT mempunyai korelasi positif dengan konsentrasi hemoglobin. Hal tersebut sejalan dengan penelitian Permaesih dan Herman (2005) yang menunjukkan bahwa remaja yang mempunyai IMT kurang atau tubuh kurus mempunyai risiko 1.5 kali untuk menjadi anemia. Berdasarkan hasil pemeriksaan status gizi remaja puteri menggunakan indeks IMT/U diketahui bahwa rata-rata remaja puteri memiliki IMT sebesar 20,52. Dari 173 remaja puteri, sebanyak 105 orang $(60,7 \%)$ remaja puteri memiliki status gizi dengan menggunakan indeks IMT/U kategori normal. Sedangkan remaja puteri yang memiliki status gizi masuk dalam kategori tidak normal menurut indeks IMT/U sebanyak 68 orang (39,3\%). Adapun secara rinci hasil pemeriksaaan IMT/U dan intepretasi status gizi remaja menurut umur 
tersaji pada Tabel 2 dan 3 berikut.

Tabel 2. Distribusi dan Frekuensi IMT

\section{KESIMPULAN DAN SARAN}

remaja puteri

\section{Kesimpulan}

Pengabdian masyarakat ini sebenarnya

\begin{tabular}{cc}
\hline IMT/U & Jumlah \\
\hline 14,00 & 6 \\
$14,01-20,00$ & 87 \\
$>20,00$ & 80 \\
\hline Jumlah & 173 \\
\hline Sumber $:$ Data primer &
\end{tabular}

Tabel 3. Distribusi dan Frekuensi Status gizi remaja puteri menurut IMT/U

\begin{tabular}{ccc}
\hline Status gizi & Jumlah & Per \\
\hline Normal & 105 \\
Tidak normal & 68 \\
\hline Jumlah & 173 \\
\hline Sumber $:$ Data primer &
\end{tabular}

Status gizi remaja merupakan kondisi tubuh yang muncul diakibatkan adanya keseimbangan antara konsumsi dan pengeluaran zat gizi. Berbagai perubahan fisiologis yang terjadi pada remaja menyebabkan penilaian status gizi pada remaja perlu mendapat perhatian khusus. Penilaian status gizi dapat diketahui melalui pengukuran secara antropometri (IMT). Masalah gizi pada remaja muncul dikarenakan perilaku gizi yang salah, yaitu ketidakseimbangan antara konsumsi gizi dengan kecukupan gizi yang dianjurkan (Hapzah, Yulita R, 2012).

Kebiasaan makan juga mempengaruhi status gizi remaja. Kebiasaan makan merupakan istilah untuk menggambarkan perilaku yang berhubungan dengan makan dan makanan seperti tata krama, frekuensi makan seseorang, pola makan yang dimakan, kepercayaan terhadap makanan (suka atau tidak suka), cara pemilihan bahan makanan yang hendak di makan. Remaja mempunyai kecenderungan untuk mengkonsumsi makanan di luar rumah atau sekolah, memilih makanan yang dianggap populer dan meningkatkan gengsi, serta mempunyai kebiasaan makan tidak teratur (Palmeira et al., 2010). Peirdaktakan(y/a) sebatas untuk melakukan pemgriksaan status gizi pada remaja putesi், 3 menurut indeks IMT/U dan mengmakan status gizi tidak normal sebes 9068 remaja puteri $(39,3 \%)$, tetapi secara tidak langsung membekali remaja puteri cara dini mendeteksi status gizi mereka agar jika terjadi masalah status gizi pada remaja puteri dengan cepat Persentasep (hallakukan intervensi bagi diri megerka sendiri mengingat remaja puteri mexerpakan salah satu golongan rawan makalah gizi karena mereka dihadapkan pada calon ibu dan dapat menjadi sumber daya manusia (SDM) yang berkualitas jika sejak dini terpenuhi kebutuhan gizinya, sehingga dapat menjadi SDM yang paling potensial untuk membantu pembangunan dalam sebuah negara karena remaja merupakan generasi penerus dan penentu masa depan bangsa.

\section{Saran}

Pihak sekolah hendaknya bekerja sama dengan Dinas Kesehatan Kabupaten Banjar agar dapat memberikan promosi kesehatan kepada para remaja puteri melalui pendidikan gizi seimbang ataupun demo masak syarat menu gizi seimbang, sehingga dengan pola makan yang berpedoman pada gizi seimbang akan menghasilkan badan sehat dengan status gizi normal.

\section{DAFTAR PUSTAKA}

Almatsier S. Prinsip Dasar Ilmu Gizi. Jakarta: Gramedia Pustaka Utama, 2010.

Badan Penelitian dan Pengembangan Kesehatan. Laporan Nasional Riset Kesehatan Dasar (Riskesdas) 2007. Jakarta: Departemen Kesehatan Republik Indonesia, 2013.

Departemen Kesehatan Pusat Data dan Informasi. Profil Kesehatan Indonesia 
2006. Jakarta: Departemen Kesehatan Republik Indonesia, 2010.

Dinas Kesehatan Kabupaten Banjar. Hasil Penilaian Status Anemia pada Remaja Puteri Siswi Sekolah Menengah Pertama (SMP)/Madrasah Tsanawiyah (Mts) Dinas Kesehatan Kabupaten Banjar. Martapura: Dinas Kesehatan Kabupaten Banjar, 2018.

Farida I. Determinan Kejadian Anemia pada Remaja Putri di Kecamatan Gebog Kabupaten Kudus Tahun 2006. Tesis. Semarang: Program Pascasarjana Universitas Diponegoro, 2018.

Gunatmaningsih D. Faktor-Faktor yang Berhubungan dengan Kejadian Anemia pada Remaja Putri di SMA Negeri 1 Kecamatan Jatibarang Kabupaten Brebes Tahun 2007. Skripsi. Semarang: Fakultas Ilmu Keolahragaan Jurusan Ilmu Kesehatan Masyarakat, 2017.

Hapzah, Yulita R. Hubungan Tingkat Pengetahuan dan Status Gizi terhadap Kejadian Anemia

Kirana DP. Hubungan Asupan Zat Gizi dan Pola Menstruasi dengan Kejadian Anemia pada Remaja Putri di SMAN 2 Semarang. Artikel Penelitian. Semarang: Program Studi Ilmu Gizi Fakultas Kedokteran Universitas Diponegoro, 2011

Nursari D. Gambaran Kejadian Anemia pada Remaja Putri SMP Negeri 18 Kota Bogor Tahun 2009. Skripsi. Jakarta: Program Studi Kesehatan Masyarakat Fakultas Kedokteran dan Ilmu Kesehatan Universitas Islam Negeri Syarif Hidayatullah, 2013.

Palmeira, A. L., Branco, T.L., Martin, S.C., Minderico, C.S., Silva, M.N., Vieira, P.N., Barata, J.T., Serpa, S.O., Sardinha, L.B., Teixeira, P.J. (2010). Change in body image and psychological well-being during behavioral obesity treatment : Associations with Weight Loss and
Maintenance. Body Image.

Permaesih D, Herman S. Faktor-Faktor yang Mempengaruhi Anemia pada Remaja. Buletin Penelitian Kesehatan, 2015; 33(4): 162-171.

Remaja Putri pada Siswi Kelas III di SMAN 1 Tinambung Kabupaten Polewali Mandar. Media Gizi Pangan, 2012; 13(1): 20-25.

Riskesdas. (2010). Riset kesehatan dasar, Jakarta: Badan Penelitian dan Pengembangan Kesehatan Kementerian Kesehatan RI.

Setijowati N, Karunia L, Magdalena N. Hubungan antara Body Image dengan Status Gizi Remaja Putri di SMA Katolik Frateran Malang. Malang: Fakultas Kedokteran Universitas Brawijaya, 2013.

World Health Organization (WHO). Iron Deficiency Anemia; Assesment, Prevention, and Control; A Guide for Programme Managers. Geneva: WHO, 2010

Yuliansyah D. Faktor - Faktor Yang Berhubungan dengan Status Gizi Remaja Putri di Sekolah Menengah Umum Negeri Toho Kabupaten Pontianak. Naskah Publikasi Skripsi. Jogjakarta: Program Studi S-1 Gizi Kesehatan Fakultas Kedokteran Universitas Gadjah Mada, 2007. 